\title{
ANALISIS PERSEPSI, KESADARAN, DAN PREFERENSI KONSUMEN TERHADAP BUAH LOKAL
}

\author{
Siti Rochaeni*
}

\begin{abstract}
ABSTRAK
Tujuan khusus dari penelitian ini, yaitu: Mengidentifikasi persepsi konsumen terhadap buah local, Mengukur kesadaran konsumen dalam konsumsi buah local, Mengidentifikasi preferensi konsumen dalam mengonsumsi buah-buahan, Menganalisis hubungan antara persepsi, kesadaran, dan preferensi konsumen terhadap buah-buahan local. Desain penelitian yang digunakan dalam penelitian ini adalah desain cross- sectional study, yaitu penelitian yang dilakukan dalam satu waktu tertentu dan tidak memantau perubahan antarwaktu. Contoh yang digunakan juga khusus untuk satu kali penelitian dan potret situasi yang dihasilkan hanya pada saat tertentu. Pengambilan data dilakukan pada minggu ketiga April 2012. Lokasi penelitian adalah kampus UIN Syarif Hidayatullah Jakarta. Pengambilan contoh dilakukan dengan teknik nonprobability sampling, tepatnya purposive sampling. metode deskripsi korelasional membutuhkan minimal 30 subyek untuk contohnya. Sebanyak 20 contoh lainnya ditambahkan sebagai penutup bila terjadi ketidak lengkapan data pada kuesioner yang diisi, sekaligus untuk memperbesar peluang data menyebar normal. Data yang telah terkumpul diolah melalui proses editing, coding, scoring, entering, dan analyzing. Analisis data dilakukan secara deskriptif dan inferensia. Persepsi konsumen terhadap buah lokal dinilai berada pada kondisi yang tidak terlalu baik, karena hanya sedikit sekali konsumen yang memiliki nilai persepsi yang tinggi. Sejalan dengan persepsi, kesadaran konsumen untuk mengonsumsi buah lokal pun belum tinggi. Ketika persepsi dan kesadaran untuk mengonsumsi buah lokal berada pada nilai yang tidak terlalu baik, dapat diprediksikan bahwa preferensi konsumen terhadap buah lokal pun akan lebih rendah, terutama saat dibandingkan dengan buah-buahan impor. Uji hubungan statistik juga mendukung pernyataan ini. Setelah uji pengaruh dilakukan juga ditemukan bahwa persepsi konsumen memiliki pengaruh nyata terhadap preferensi.
\end{abstract}

Kata Kunci: Persepsi, Kesadaran, Sikap, Preferensi, Buah Lokal, Konsumen 


\begin{abstract}
Food security and sovereignity related to the existence of a nation and a state. Many of the nations wiped off the map of the world as they face food issues. The rate of conversion of agricultural land in Indonesia will lead to dependence on food imports, which resulted in the loss of food sovereignity. On the basis of in-depth study of literature, It has proved that the desire and managing agricultural land in Indonesia is based solely on the rural culture that ownership of agricultural land and food security is a symbol of wealth and honor. The farmers do not think profit and commercial. However, this culture is fading due to the inclusion of commercialization and economic money into the rural in line with the modernization of the countryside. With the principles of commercialization, conversion of land will be the right choice, because businesses in the sector of food agricultural is not profitable. On the other hand, Indonesian goverment has not found the right formula to make the food agricultural is profitable for small scale land farmer as to reduce the rate of land conversion.
\end{abstract}

Keywords: conversion, food security, food sovereignity, land

\section{PENDAHULUAN}

\section{Latar Belakang}

Menurut data Biro Pusat Statistik (BPS) pada tahun 2010, jumlah penduduk Indonesia telah mencapai lebih dari 230 juta jiwa dengan jumlah pertumbuhan rata-rata 1,49 persen setiap tahunnya. Banyaknya jumlah penduduk mencerminkan Indonesia merupakan pasar yang sangat potensial bagi produsen dan pemasar, tidak terkecuali untuk pasar buah-buahan segar. Terjadi peningkatan konsumsi buah dari tahun-ke tahun. Hal ini disebabkan oleh pendapatan masyarakat yang cenderung meningkat.

Dalam era globalisasi yang mengarah pada pasar bebas, berbagai produk luar negeri semakin memenuhi pasar tanah air. Sejak dibukanya jalur impor buah pada tahun 1999 dengan disahkannya (AFTA) yang dilanjutkan dengan penandatanganan China-ASEAN Free Trade Agreement (CAFTA) oleh pemerintah Indonesia, buah-buahan impor semakin berpeluang untuk memasuki pasar Indonesia. Data BPS (2009) menunjukkan angka impor buah-buahan dari Cina yang terus meningkat, hingga mencapai US\$ 330,99 juta sepanjang tahun 2009.

Banyaknya jumlah buah-buahan impor dengan kualitas yang dinilai baik semakin menurunkan posisi buah-buahan lokal sebagai akibat meningkatnya persaingan pasar. Dalam jangka panjang, hal ini dapat memberikan dampak negatif bagi perekonomian usaha produk dalam negeri. Tingkat konsumsi masyarakat terhadap buah-buahan impor pun mengalami peningkatan, yang menunjukkan adanya gejala pergeseran konsumsi dari buah lokal beralih menjadi buah impor.

Data yang telah terkumpul diolah melalui proses editing, coding, scoring, entering, dan analyzing. Analisis data dilakukan secara deskriptif dan inferensia. Analisis 
data yang digunakan untuk masing-masing variabel adalah sebagai berikut:

Terjadinya pergeseran perilaku konsumsi merupakan indikasi adanya pergeseran persepsi konsumen mengenai buah lokal. Persepsi akan menggiring konsumen membangun sebuah kesadaran terhadap produk ini. Persepsi dan kesadaran akan membentuk sikap konsumen dalam memilih produk mana yang akan dikonsumsinya, baik itu buah lokal maupun buah impor. Produk yang dipilih merupakan produk yang lebih disukai oleh konsumen berdasarkan preferensi konsumen tersebut. Oleh karena itu, penelitian ini difokuskan untuk melihat bagaimana persepsi, kesadaran, dan preferensi konsumen terhadap buah lokal, serta hubungan antara variabel-variabel tersebut.

\section{Perumusan Masalah}

Buah merupakan salah satu jenis pangan sumber vitamin dan mineral yang memiliki peran penting bagi tubuh manusia. Di era globalisasi saat ini, kesempatan bagi buah impor untuk memasuki pasar dalam negeri berpotensi menggeser persepsi masyarakat mengenai citra buah lokal.

Persepsi konsumen yang yang merupakan hasil dari berbagai informasi yang diperoleh konsumen akan menimbulkan kesadaran konsumen untuk mengonsumsi atau tidak mengonsumsi buah lokal. Hal ini akan berpengaruh terhadap cara konsumen membuat keputusan konsumsi buah, apakah konsumen akan memilih untuk mengonsumsi buah lokal atau justru buah impor. Inilah yang kemudian disebut sebagai preferensi konsumen. Proses yang dialami konsumen hingga terbentuk suatu preferensi merupakan suatu rangkaian yang saling terkait. Walaupun demikian, perlu dikaji lebih lanjut mengenai kekuatan hubungan variabel-variabel tersebut pada kajian mengenai produk buah lokal.

Berdasarkan beberapa pemaparan di atas, beberapa hal penting yang perlu dikaji dalam penelitian ini, antara lain:

1. Bagaimana persepsi konsumen terhadap buah lokal?

2. Bagaimana kesadaran konsumen dalam konsumsi buah lokal?

3. Bagaimana preferensi konsumen dalam mengonsumsi buah-buahan?

4. Apakah terdapat hubungan antara persepsi, kesadaran, dan preferensi konsumen terhadap buah-buahan lokal?

\section{Tujuan}

Tujuan Umum

Secara umum penelitian ini bertujuan untuk mengetahui persepsi, kesadaran, dan preferensi konsumen terhadap buah-buahan lokal.

\section{Tujuan Khusus}

Tujuan umum yang telah disebutkan dapat diperinci menjadi beberapa tujuan khusus. Tujuan khusus dari penelitian ini, yaitu:

1. Mengidentifikasi persepsi konsumen terhadap buah lokal

2. Mengukur kesadaran konsumen dalam konsumsi buah lokal

3. Mengidentifikasi preferensi konsumen dalam mengonsumsi buah-buahan 
4. Menganalisis hubungan antara persepsi, kesadaran, dan preferensi konsumen terhadap buah-buahan lokal

\section{TINJAUAN PUSTAKA}

\section{Persepsi}

Menurut Engel, Blackwell, dan Miniard (1995), terdapat lima tahap dalam pengolahan informasi, yaitu pemaparan, perhatian, pemahaman, peneriman, dan retensi. Persepsi sendiri disebutkan melingkupi tahap pemaparan, perhatian, dan pemahaman (Mowen \& Minor 1999).

Konsumen seringkali memutuskan pembelian suatu produk berdasarkan persepsinya terhadap produk tersebut (Sumarwan 2004). Persepsi, menurut Mowen dan Minor (1999) ialah proses keseluruhan di mana individu terpapar pada informasi, mengikuti informasi tersebut, dan memahaminya. Schiffman dan Kanuk (2000) mengartikan persepsi sebagai proses di mana individu memilih, mengelola, dan menginterpretasikan stimulus menjadi gambaran yang bermakna dan koheren.

\section{Kesadaran}

Kesadaran dapat dikatakan sebagai tahap pertama dari proses adopsi terhadap suatu produk atau ide baru. Kesadaran adalah suatu keadaan ketika konsumen menyadari keberadaan suatu produk. Kesadaran produk hanya sebatas kesadaran konsumen atas keberadaan suatu produk, namun informasi yang diketahui seputar produk tersebut masih sedikit (Kotler \& Armstrong 2008).

Kesadaran yang dialami individu tidak datang begitu saja, melainkan dibangun oleh kebutuhan, pengetahuan tentang atribut produk baru, pengalaman konsumsi di masa lalu, dan juga keinovatifan seseorang. Kesadaran konsumen diukur untuk mengetahui sejauh mana pengetahuan konsumen mengenai keberadaan suatu produk (Peter \& Olson 1996).

Suatu kesadaran diharapkan bisa berujung pada adopsi terus-menerus. Jika produk yang ada berupa barang, maka memilih produk berarti membeli produk dan mempelajari bagaimana cara mengunakannya serta kemudian mempertahankannya. Jika produk yang ada berupa ide, maka memilih produk berarti konsumen tersebut setuju dengan suatu ide (Nurasrina 2010).

\section{Preferensi}

Preferensi konsumen merupakan keputusan evaluasi konsumen dengan mempertimbangkan dua atau lebih obyek. Preferensi selalu melibatkan pembandingan antar-obyek. Menurut Kotler (2005), preferensi konsumen adalah derajat kesukaan seseorang terhadap suatu jenis produk. Preferensi terhadap produk pangan merupakan gambaran atas sikap seseorang terhadap pangan dan seseorang dapat melakukan gambaran atas sikap seseorang terhadap pangan dan seseorang dapat melakukan pilihan dari produk yang ada sedikitnya dua jenis pangan yang berbeda.

Menurut Kotler (2000), ada tiga komponen preferensi yang mempengaruhi konsumen pangan dimana semua komponen tersebut saling mempengaruhi dan berkaitan satu sama lain yaitu: 
1. Karakteristik individu

2. Karakteristik produk

3. Karakteristik lingkungan

\section{Kerangka Pemikiran}

Proses pengambilan keputusan berawal dari pengenalan kebutuhan yang bisa dimunculkan oleh faktor diri konsumen sendiri (internal) maupun faktor di luar diri konsumen (eksternal). Dalam penelitian ini, faktor internal dikatakan sebagai karakteristik individu dan meliputi karakteristik demografi (jenis kelamin dan usia), serta karakteristik ekonomi (pendapatan). Menurut Sumarwan (2004), memahami usia konsumen adalah penting karena perbedaan usia akan mengakibatkan perbedaan selera dan kesukaan terhadap suatu produk.

Berbagai stimulus yang diterima konsumen dari lingkungannya akan berinteraksi dengan karakteristik internal konsumen dan membentuk persepsi dan kesadarannya terhadap suatu produk. Persepsi dan kesadaran kemudian menentukan pengambilan keputusan yang dilakukan konsumen melalui pemilihan jenis produk yang akan dikonsumsi (preferensi konsumen). Secara lebih singkat, kerangka penelitian ini dapat dilihat pada Gambar 1.

\section{METODE PENELITIAN}

\section{Desain, Waktu, dan Lokasi}

Desain penelitian yang digunakan dalam penelitian ini adalah desain crosssectional study, yaitu penelitian yang dilakukan dalam satu waktu tertentu dan tidak memantau perubahan antarwaktu. Contoh yang digunakan juga khusus untuk satu kali penelitian dan potret situasi yang dihasilkan hanya pada saat tertentu. Pengambilan data dilakukan pada minggu ketiga April 2012. Lokasi penelitian adalah kampus UIN Syarif Hidayatullah Jakarta.

\section{Teknik Pengambilan Contoh}

Pengambilan contoh dilakukan dengan teknik nonprobability sampling, tepatnya purposive sampling. Jumlah contoh yang digunakan dalam penelitian ini berjumlah 50 orang. Jumlah ini mengacu pada Gay dalam Umar (2005) yang menyatakan bahwa metode deskripsi korelasional membutuhkan minimal 30 subyek untuk contohnya. Sebanyak 20 contoh lainnya ditambahkan sebagai penutup bila terjadi ketidaklengkapan data pada kuesioner yang diisi, sekaligus untuk memperbesar peluang data menyebar normal.

\section{Jenis dan Cara Pengumpulan Data}

Data-data yang digunakan dalam penelitian ini adalah data primer. Data primer diperoleh dari hasil wawancara dengan panduan kuesioner. Data ini meliputi karakteristik contoh, persepsi, kesadaran, dan preferensi contoh.

\section{Pengolahan dan Analisis Data}

Data yang telah terkumpul diolah melalui proses editing, coding, scoring, entering, dan analyzing. Analisis data dilakukan secara deskriptif dan inferensia. Analisis data yang digunakan untuk 


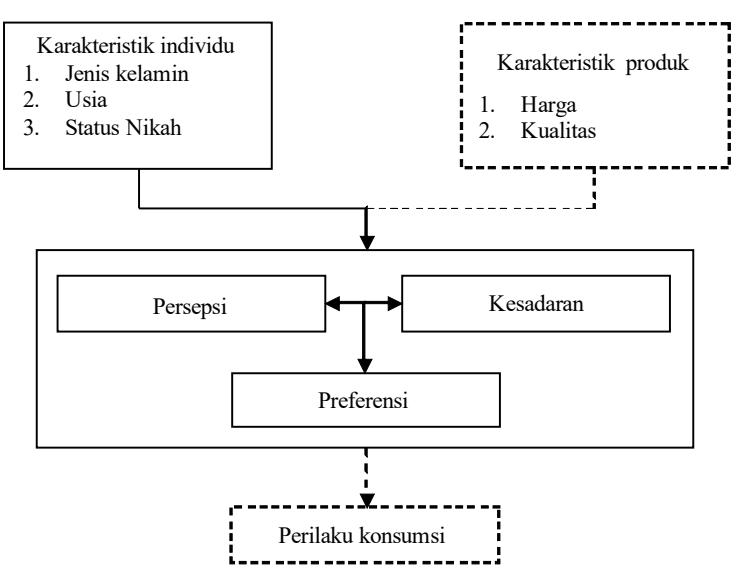

Gambar 10. Kerangka Pemikiran "Persepsi, Kesadaran, dan Preferensi Konsumsi Buah Lokal"

Keterangan:

$$
\begin{aligned}
& \square=\text { Variabel yang diteliti } \\
& \longrightarrow \quad=\text { Variabel yang tidak diteliti } \\
& \longrightarrow \quad \text { = hubungan yang diteliti }
\end{aligned}
$$

masing-masing variabel adalah sebagai berikut:

1. Karakteristik konsumen, terdiri dari jenis kelamin, usia, dan status pernikahan, dianalisis dengan menggunakan statistik deskriptif. Statistik deskriptif dimaksudkan untuk memberi makna pada data karakteristik konsumen.

2. Persepsi dianalisis dengan menggunakan statistik deskriptif. Variabel ini diukur dengan sepuluh pernyataan tertutup. Terdapat lima pilihan jawaban dalam skala Likert yang diberi pembobotan, yaitu 5 untuk jawaban "sangat setuju", 4 untuk jawaban "setuju", 3 untuk jawaban "kurang setuju", 2 untuk jawaban "tidak setuju", dan 1 untuk jawaban "sangat tidak setuju". Hasil skor total untuk media ini merupakan penjumlahan bobot setiap pertanyaan dengan nilai tertinggi 49 dan nilai terendah 23, yang kemudian dikategorikan menjadi tiga dengan interval yang didasarkan pada rumus menurut Slamet (1993), yaitu: Interval (I) $=$ Nilai Tertinggi - Nilai Terendah

\section{Jumlah Kelas}

Kesadaran dianalisis dengan menggunakan statistik deskriptif. Sebanyak sembilan pernyataan tertutup dan positif digunakan untuk mengukur variabel ini melalui skala Likert dengan lima pembobotan. Skor total untuk variabel ini merupakan jumlah pembobotan tiap pertanyaan. Skor ini kemudian dibagi ke dalam tiga kategori berdasarkan interval yang diperoleh melalui rumus yang diacu dalam Slamet (1993). Nilai tertinggi untuk variabel kesadaran adalah 44 dan nilai terendahnya 22 .

4. Preferensi dianalisis dengan menggunakan statistik deskriptif. Preferensi konsumen diukur dengan menggunakan skala semantik diferensial untuk melihat kecenderungan konsumen dalam menyukai buah lokal atau buah impor. Hasilnya kemudian diberi bobot dan dijumlahkan, serta dibagi ke dalam tiga kategori berdasarkan interval yang diperoleh melalui rumus yang diacu dalam Slamet (1993) dengan nilai tertinggi 5 dan nilai terendah 0 .

5. Hubungan antarvariabel dianalisis dengan uji korelasi Pearson. Hubungan yang dianalisis yaitu 
antara persepsi, kesadaran, dan preferensi.

6. Pengaruh variabel persepsi dan kesadaran terhadap preferensi dianalisis dengan menggunakan uji regresi linier berganda. Sebelum dilakukan uji pengaruh, skor preferensi terlebih dulu dikonversi dalam bentuk dummy, yaitu 1 bila konsumen cenderung pada buah lokal dan 0 bila konsumen cenderung pada buah impor. Definisi Operasional

Konsumen adalah contoh dalam penelitian.

Karakteristik konsumen adalah ciri-ciri individu yang meliputi jenis kelamin, usia, dan status pernikahan.

Persepsi adalah cara pandang konsumen terhadap produk buah lokal jika dibandingkan dengan buah impor.

Kesadaran adalah keyakinan konsumen terhadap pentingnya mengonsumsi buah lokal karena adanya stimulus dari dalam diri ataupun dari luar.

Preferensi adalah tingkat kesukaan konsumen terhadap buah lokal jika dibandingkan dengan buah impor.

\section{HASIL PENELITIAN}

\section{Karakteristik Konsumen}

1. Jenis Kelamin

Lebih dari separuh konsumen $(58,0 \%)$ berjenis kelamin perempuan, sementara 42,0 persen sisanya laki-laki. Perbandingan jumlah konsumen laki-laki dan perempuan tidak terlalu berbeda jauh.
Sebaran konsumen berdasarkan jenis kelamin dapat dilihat pada Tabel 1.

Tabel 37. Sebaran Konsumen Berdasarkan Jenis Kelamin

\begin{tabular}{ccc}
\hline $\begin{array}{c}\text { Jenis } \\
\text { Kelamin }\end{array}$ & $\begin{array}{c}\text { Jumlah } \\
(\mathbf{n})\end{array}$ & $\begin{array}{c}\text { Persentase } \\
(\mathbf{\%})\end{array}$ \\
\hline Laki-laki & 21 & 42 \\
Perempuan & 29 & 58 \\
\hline Total & $\mathbf{5 0}$ & $\mathbf{1 0 0}$ \\
\hline
\end{tabular}

2. Usia

Perbedaan usia konsumen dapat mempengaruhi selera dan kesukaannya terhadap suatu produk (Sumarwan 2004). Siklus hidup seorang konsumen juga akan ditentukan oleh usianya. Konsumen termuda dalam penelitian ini berusia 18 tahun, sementara yang tertua berusia 53 tahun. Rataan usia konsumen adalah 23,8 tahun. Jumlah konsumen terbanyak terdapat pada elompok usia dewasa awal (76,0\%)Sebaran konsumen berdasarkan usia secara lebih rinci ditampilkan pada Tabel 2.

Tabel 38. Sebaran Konsumen Berdasarkan

Usia

\begin{tabular}{lcr}
\hline \multicolumn{1}{c}{ Usia (th) } & $\begin{array}{c}\text { Jumlah } \\
(\mathbf{n})\end{array}$ & \multicolumn{1}{c}{$\begin{array}{c}\text { Persentase } \\
(\mathbf{\%})\end{array}$} \\
\hline Remaja lanjut (16- & & \\
18) & 1 & 2.0 \\
Dewasa awal (19- & & 76.0 \\
24) & 38 & 8.0 \\
Dewasa lanjut (25- & & \\
35) & 4 & 12.0 \\
Separuh baya (36- & & 2.0 \\
50) & 6 & $\mathbf{1 0 0 , 0}$ \\
Tua (51-65) & 1 & $18-53$ \\
\hline Total & $\mathbf{5 0}$ & $23,8 \pm 9,3$ \\
\hline $\begin{array}{l}\text { Minimum- } \\
\text { maksimum }\end{array}$ & & \\
Rataan \pm Standar & & \\
Deviasi & &
\end{tabular}


3. Status Pernikahan

Sebaran konsuen berdasarkan status pernikahan dapat dilihat pada Tabel 3 di bawah ini:

Tabel 39. Sebaran Konsumen Berdasarkan Status Pernikahan

\begin{tabular}{lcc}
\hline $\begin{array}{c}\text { Status } \\
\text { Pernikahan }\end{array}$ & $\begin{array}{c}\text { Jumlah } \\
\text { (n) }\end{array}$ & $\begin{array}{c}\text { Persentase } \\
\text { (\%) }\end{array}$ \\
\hline Belum menikah & 41 & 82,0 \\
Menikah & 9 & 18,0 \\
\hline Total & $\mathbf{5 0}$ & $\mathbf{1 0 0 , 0}$ \\
\hline
\end{tabular}

Sebagian besar konsumen $(82,0 \%)$ merupakan individu yang belum menikah. Hanya $18,0 \%$ konsumen yang telah menikah. Hal ini diduga memiliki keterkaitan dengan usia konsumen yang didominasi kelompok dewasa awal dengan rentang usia 19 hingga 24 tahun.

\section{Persepsi}

Sepuluh pernyataan diberikan kepada konsumen untuk mengetahui persepsi konsumen tentang konsumsi buahbuahan lokal. Sebagian besar jawaban terpusat pada pilihan "setuju", kecuali pada pernyataan nomor 5 mengenai penampilan fisik buah lokal. Tabel 4 menunjukkan sebaran konsumen berdasarkan jawaban terhadap persepsi konsumsi buah-buahan lokal.

Setelah dilakukan penilaian terhadap persepsi konsumen, diketahui skor persepsi tersebut masih belum tinggi. Hal ini terlihat dari proporsi konsumen yang memiliki skor persepsi yang masih rendah hampir sepertiga dari jumlah total konsumen (32,0\%), sementara yang memiliki skor sedang memiliki jumlah konsumen terbanyak dengan 62,0 persen, seperti yang terlihat pada Tabel 5 . Konsumen dengan persepsi yang tergolong tinggi justru menempati proporsi terendah dengan hanya mencapai 6,0 persen.

Dari seluruh pernyataan yang diberikan dan dengan total skor 50 poin, skor terendah yang dicapai konsumen adalah 23 poin, sementara skor tertinggi adalah 49 poin. Rataan dari skor adalah 34,0 poin. Skor rataan ini termasuk ke dalam kategori sedang, dengan standar deviasi sebesar 5,0.

Tabel 40. Sebaran Konsumen Berdasarkan Jawaban Terhadap Persepsi Konsumsi Buah Lokal

\begin{tabular}{clrrrrrr}
\hline \multirow{2}{*}{ No } & \multicolumn{1}{c}{ Pernyataan } & \multicolumn{4}{c}{ Jumlah $(\%)$} & Total \\
\cline { 3 - 6 } & & SS & S & KS & TS & STS & (\%) \\
\hline 1. & Perbandingan buah lokal dan impor & 14.0 & 44.0 & 32.0 & 10.0 & 0.0 & 100,0 \\
2. & Khasiat buah lokal & 20.0 & 48.0 & 32.0 & 0.0 & 0.0 & 100,0 \\
3. & Kemudahan memperoleh buah lokal & 12.0 & 38.0 & 26.0 & 22.0 & 2.0 & 100,0 \\
4. & Kualitas buah lokal & 14.0 & 48.0 & 20.0 & 16.0 & 2.0 & 100,0 \\
5. & Penampilan buah lokal & 4.0 & 6.0 & 24.0 & 48.0 & 18.0 & 100,0 \\
6. & Citra buah lokal & 12.0 & 28.0 & 16.0 & 36.0 & 8.0 & 100,0 \\
7. & Harga buah lokal & 20.0 & 50.0 & 8.0 & 18.0 & 4.0 & 100,0 \\
8. & Rasa buah lokal & 20.0 & 52.0 & 20.0 & 6.0 & 2.0 & 100,0 \\
9. & Prestise buah lokal & 4.0 & 22.0 & 32.0 & 34.0 & 8.0 & 100,0 \\
10. & Kekhususan buah lokal & 40.0 & 40.0 & 8.0 & 10.0 & 2.0 & 100,0 \\
\hline
\end{tabular}


Tabel 41. Sebaran Konsumen Berdasarkan Skor Persepsi Konsumsi Buah Lokal

\begin{tabular}{lrr}
\hline \multicolumn{1}{c}{ Kesadaran } & Jumlah (n) & Persentase (\%) \\
\hline Rendah (23-31) & 16 & 32.0 \\
Sedang (32-40) & 31 & 62.0 \\
Tinggi (41-49) & 3 & 6.0 \\
\hline Jumlah & $\mathbf{5 0}$ & 100,0 \\
\hline Minimum - Maksimum & & $23,0-49,0$ \\
Rataan \pm Standar Deviasi & & $34,0 \pm 5,0$ \\
\hline
\end{tabular}

Tabel 42. Sebaran Konsumen Berdasarkan Jawaban Terhadap Kesadaran Konsumsi Buah Lokal

\begin{tabular}{clrrrrrr}
\hline \multirow{2}{*}{ No. } & \multicolumn{1}{c}{ Pernyataan } & \multicolumn{3}{c}{ Jumlah (\%) } & Total \\
\cline { 3 - 6 } & & SS & S & KS & TS & STS & $(\%)$ \\
\hline 1. & Pencarian informasi & 10.0 & 22.0 & 8.0 & 32.0 & 28.0 & 100,0 \\
2. & Kemampuan identifikasi & 22.0 & 44.0 & 20.0 & 12.0 & 2.0 & 100,0 \\
3. & Dampak ekonomi & 76.0 & 24.0 & 0.0 & 0.0 & 0.0 & 100,0 \\
4. & Cinta produk dalam negeri & 52.0 & 32.0 & 12.0 & 4.0 & 0.0 & 100,0 \\
5. & Kebanggan terhadap produk & & & & & & 100,0 \\
& dalam negeri & 46.0 & 40.0 & 10.0 & 4.0 & 0.0 & \\
6. & Prioritas konsumsi buah lokal & & & & & & 100,0 \\
& & 18.0 & 42.0 & 26.0 & 14.0 & 0.0 & \\
7. & Rasa nasionalisme & 42.0 & 34.0 & 18.0 & 4.0 & 2.0 & 100,0 \\
8. & Merek buah impor & 24.0 & 42.0 & 24.0 & 10.0 & 0.0 & 100,0 \\
9. & Tradisi konsumsi buah & 6.0 & 38.0 & 22.0 & 22.0 & 12.0 & 100,0 \\
\hline
\end{tabular}

\section{Kesadaran}

Sembilan pernyataan diberikan kepada konsumen untuk mengetahui kesadaran konsumen untuk mengonsumsi buah-buahan lokal. Sebagian besar jawaban terpusat pada pilihan setuju, kecuali pada pernyataan nomor 1 mengenai upaya pencarian informasi yang dilakukan konsumen. Tabel 6 menunjukkan sebaran konsumen berdasarkan jawaban terhadap kesadaran untuk mengonsumsi buahbuahan lokal. Sebagian besar jawaban konsumen cenderung pada pilihan setuju dan sangat setuju.

Kesadaran konsumen untuk mengonsumsi buah lokal dapat dikatakan cukup baik dengan 30 persen konsumen tergolong dalam kategori tinggi dan 58 persen dalam kategori sedang. Kesadaran ini diharapkan dapat berlanjut menjadi adopsi yang terus-menerus. Rinciannya sebaran konsumen berdasarkan skor kesadaran konsumsi buah lokal dapat dilihat pada Tabel 7.

Dari total sembilan pernyataan yang diberikan dan dengan total skor maksimum 45 poin, skor terendah yang dicapai konsumen adalah 22 poin, sementara skor tertinggi adalah 44 poin. Rataan dari skor adalah 34,2 poin. Skor rataan ini termasuk ke dalam kategori sedang, dengan standar deviasi sebesar 4,6. 
Tabel 43. Sebaran Konsumen Berdasarkan Skor Kesadaran Konsumsi Buah Lokal

\begin{tabular}{lcc}
\hline \multicolumn{1}{c}{ Kesadaran } & Jumlah (n) & $\begin{array}{c}\text { Persentase } \\
(\mathbf{\%})\end{array}$ \\
\hline Rendah (22- & & \\
29) & 6 & 12.0 \\
Sedang (30-37) & 29 & 58.0 \\
Tinggi (38-45) & 15 & 30.0 \\
\hline Jumlah & $\mathbf{5 0}$ & 100,0 \\
\hline Minimum - & & $22,0-44,0$ \\
Maksimum & & \\
Rataan \pm & & $34,2 \pm 4,6$ \\
Standar & & \\
Deviasi & & \\
\hline
\end{tabular}

\section{Preferensi}

Dalam penelitian ini, preferensi konsumen diukur dari lima aspek, yaitu rasa, penampilan, harga, kemudaan mendapatkan, dan prestise, dengan membandingkan antara buah lokal dan buah impor. Seperti terlihat pada Tabel 8, sebagian besar konsumen lebih memilih untuk mengonsumsi buah impor karena aspek penampilan, harga, kemudahan mndapatkan, dan prestise dari buah impor tersebut. Sementara itu, hanya aspek rasa buah lokal yang membuatnya lebih dipilih konsumen, walaupun dengan perbandingan yang tidak berbeda jauh dengan buah impor.

Tabel 44. Sebaran Konsumen Berdasarkan Preferensi Konsumsi Buah Lokal dan Buah Impor

\begin{tabular}{lrrr}
\hline \multirow{2}{*}{ Pernyataan } & \multicolumn{2}{c}{ Jumlah (\%) } & Total \\
\cline { 2 - 3 } & $\begin{array}{r}\text { Buah } \\
\text { Lokal }\end{array}$ & $\begin{array}{r}\text { Buah } \\
\text { Impor }\end{array}$ & \\
\hline Rasa & 52.0 & 48.0 & 100,0 \\
Penampilan & 14.0 & 86.0 & 100,0 \\
Harga & 32.0 & 68.0 & 100,0 \\
Kemudahan & & & 100,0 \\
didapat & 24.0 & 76.0 & \\
Prestise & 18.0 & 82.0 & 100,0 \\
\hline
\end{tabular}

Tabel 8, Tabel 9 menampilkan skor konsumen untuk preferensi buah lokal yang juga sebagian besar berada pada kategori rendah (60,0\%). Hanya 8,0 persen konsumen yang memiliki preferensi tinggi untuk mengonsumsi buah lokal. Dengan total skor maksimum 5 poin yang berarti terdapat konsumen yang sepenuhnya lebih memilih buah lokal daripada buah impor, nilai minimum yang didapat adalah 0 poin yang mengindikasikan terdapat konsumen yang sepenuhnya lebih memilih buah impor daripada buah lokal.

Tabel 45. Sebaran Konsumen Berdasarkan Skor Preferensi Konsumsi Buah Lokal

\begin{tabular}{lrr}
\hline Kesadaran & \multicolumn{1}{c}{$\begin{array}{c}\text { Jumlah } \\
\text { (n) }\end{array}$} & \multicolumn{1}{c}{$\begin{array}{c}\text { Persentase } \\
(\%)\end{array}$} \\
\hline Rendah (0-1) & 30 & 60.0 \\
Sedang (2-3) & 16 & 32.0 \\
Tinggi (4-5) & 4 & 8.0 \\
\hline Jumlah & $\mathbf{5 0}$ & 100,0 \\
\hline Minimum - & & $0,0-5,0$ \\
Maksimum & & \\
Rataan \pm & & \\
Standar & & $1,4 \pm 1,3$ \\
Deviasi & & \\
\hline
\end{tabular}

\section{Hubungan Antarvariabel}

Uji korelasi Pearson dilakukan untuk mengetahui kekuatan hubungan antara variabel persepsi, kesadaran, dan preferensi. Hasil uji korelasi ini, seperti ditampilkan pada Tabel 10, menunjukkan hubungan yang sangat nyata pada hubungan variabel persepsi dengan kesadaran $\left(\mathrm{r}=0,484^{* *}\right)$ dan preferensi $\left(\mathrm{r}=0,48^{* *}\right)$. Sementara itu, variabel kesadaran dan preferensi memiliki hubungan yang nyata dengan $\mathrm{r}=0,338^{*}$. 
Tabel 46. Koefisien Korelasi Antarvariabel Persepsi, Kesadaran, dan Preferensi Konsumen Buah Lokal

\begin{tabular}{lccc}
\hline \multirow{2}{*}{ Variabel } & \multicolumn{3}{c}{ Koefisien Korelasi Pearson (r) } \\
\cline { 2 - 4 } & $\begin{array}{c}\text { Perseps } \\
\text { i }\end{array}$ & $\begin{array}{c}\text { Kesadara } \\
\text { n }\end{array}$ & $\begin{array}{c}\text { Preferens } \\
\mathbf{i}\end{array}$ \\
\hline Persepsi & 1 & $0,484^{* *}$ & $0,448^{* *}$ \\
Kesadara & - & 1 & $0,338^{*}$ \\
$\mathrm{n}$ & & & \\
Preferensi & - & - & 1 \\
\hline
\end{tabular}

Keterangan: * nyata pada $\mathrm{P}<0.05$

** sangat nyata pada $\mathrm{P}<0.01$

\section{Faktor-faktor yang Berpengaruh terhadap Preferensi Konsumen}

Berdasarkan hasil uji korelasi, variabel persepsi dan kesadaran diduga memiliki pengaruh yang signifikan terhadap pembentukan preferensi konsumen untuk mengonsumsi buah lokal. Setelah melalui uji regresi linier berganda, hasil uji statistik tersebut menunjukkan hanya variabel kesadaran yang memiliki pengaruh signifikan terhadap preferensi konsumen dengan nilai $\beta$ sebesar 0,096 (Tabel 11). Dapat diartikan, setiap kenaikan 1 poin skor persepsi akan meningkatkan preferensi konsumen untuk mengonsumsi buah lokal sebesar 0,096 poin.

Tabel 47. Faktor-faktor yang Berpengaruh terhadap Preferensi Konsumsi Buah Lokal

\begin{tabular}{lccc}
\hline $\begin{array}{c}\text { Variab } \\
\text { el }\end{array}$ & $\begin{array}{c}\text { Koefisien } \boldsymbol{\beta} \\
\text { Belum } \\
\text { Terstandardi } \\
\text { sasi }\end{array}$ & $\begin{array}{c}\text { Koefisien } \boldsymbol{\beta} \\
\text { Terstandardi } \\
\text { sasi }\end{array}$ & $\begin{array}{c}\text { Nilai } \\
\text { Signifika } \\
\text { nsi }\end{array}$ \\
\hline Persepsi & 0,096 & 0,371 & $0,015^{*}$ \\
$\begin{array}{l}\text { Kesadar } \\
\text { an }\end{array}$ & 0,045 & 0,158 & 0,287 \\
\hline
\end{tabular}

Koefisien determinasi yang telah disesuaikan (Adjusted $R$ square) yang diperoleh dari model regresi ini adalah 0,187 . Angka ini mengartikan bahwa model egresi ini hanya menjelaskan 18,7 persen pengaruh persepsi dan kesadaran terhadap preferensi konsumen dalam memilih buah yang akan dikonsumsi. Sisanya $(81,3 \%)$ dipengaruhi oleh variabel yang tidak diteliti dan atau dimasukkan ke dalam model regresi.

\section{PEMBAHASAN}

Jumlah konsumen perempuan lebih banyak daripada konsumen laki-laki. Selain itu, dominasi konsumen berusia remaja lanjut yang kemudian diduga memiliki keterkaitan dengan banyaknya jumlah konsumen yang berstatus belum menikah terlihat jelas pada penelitian ini.

Persepsi menunjukkan bagaimana konsumen melihat realitas yang ada di luar dirinya atau di lingkungan sekitarnya. Walaupun terpapar pada stimulus yang sama, persepsi yang dihasilkan akan berbeda pada konsumen yang berbeda (Sumarwan 2004). Hal ini terjadi karena stimulus bukanlah satu-satunya faktor yang mempengaruhi persepsi. Persepsi konsumen terhadap buah lokal dinilai berada pada kondisi yang tidak terlalu baik, karena hanya sedikit sekali konsumen yang memiliki nilai persepsi yang tinggi.

Sejalan dengan persepsi, kesadaran konsumen untuk mengonsumsi buah lokal pun belum tinggi. Hal ini diperkuat dengan hasil analisis statistik yang menunjukkan signifikansi yang sangat nyata dalam hubungan antara persepsi dan kesadaran. Walaupun demikian, jumlah konsumen dengan skor kesadaran yang tinggi masih 
lebih banyak dibandingkan dengan skor persepsinya. Nilai kesadaran terrendah terdapat pada pertanyaan yang berkaitan dengan upaya pencarian informasi yang dilakukan konsumen sebelum melakukan tindakan konsumsi buah, terutama buah lokal. Jika hal ini dikaitkan dengan persepsi, maka akan diketahui bahwa persepsi yang rendah akan mengurangi keterlibatan konsumen dalam proses pencarian informasi mengenai suatu produk. Menurut Sumarwan (2004), persepsi bersama dengan keterlibatan konsumen dan memori akan mempengaruhi pengolahan informasi.

Ketika persepsi dan kesadaran untuk mengonsumsi buah lokal berada pada nilai yang tidak terlalu baik, dapat diprediksikan bahwa preferensi konsumen terhadap buah lokal pun akan lebih rendah, terutama saat dibandingkan dengan buah-buahan impor. Uji hubungan statistik juga mendukung pernyataan ini. Setelah uji pengaruh dilakukan juga ditemukan bahwa persepsi konsumen memiliki pengaruh nyata terhadap preferensi.

Hasil penelitian mengungkapkan bahwa konsumen lebih memilih buah impor karena pertimbangan aspek penampilan, harga, kemudahan mendapatkan, serta prestise buah impor. Dari keempat aspek ini, nilai yang paling tinggi didapat dari aspek penampilan buah impor yang dinilai lebih baik dan menarik. Sementara itu, buah lokal sedikit lebih unggul di mata konsumen dari aspek rasa, yang dinilai lebih segar. Sumarwan (2004) dalam bukunya memaparkan bahwa konsumen Indonesia dikenal sebagai konsumen yang cenderung lebih menyukai produk impor karena dianggap lebih berkualitas daripada produk lokal, terutama yang berasal dari negara- negara maju, seperti Amerika Serikat dan Jepang.

\section{PENUTUP}

\section{Kesimpulan}

Persepsi konsumen terhadap buah lokal dinilai berada pada kondisi yang tidak terlalu baik, karena hanya sedikit sekali konsumen yang memiliki nilai persepsi yang tinggi. Sejalan dengan persepsi, kesadaran konsumen untuk mengonsumsi buah lokal pun belum tinggi. Ketika persepsi dan kesadaran untuk mengonsumsi buah lokal berada pada nilai yang tidak terlalu baik, dapat diprediksikan bahwa preferensi konsumen terhadap buah lokal pun akan lebih rendah, terutama saat dibandingkan dengan buah-buahan impor. Uji hubungan statistik juga mendukung pernyataan ini. Setelah uji pengaruh dilakukan juga ditemukan bahwa persepsi konsumen memiliki pengaruh nyata terhadap preferensi.

impor karena pertimbangan aspek penampilan, harga, kemudahan mendapatkan, serta prestise. Dari keempat aspek ini, nilai yang paling tinggi didapat dari aspek penampilan buah impor yang dinilai lebih baik dan menarik. Sementara itu, buah lokal sedikit lebih unggul di mata konsumen dari aspek rasa, yang dinilai lebih segar.

\section{Saran}

Kepada konsumen, buah impor memang berpenampilan menarik dibandingkan buah lokal tetapi buah lokal tidak kalah menarik daripada buah impor. 
Kepada Produsen, agar dilakukan penanganan pasca panen yang lebih baik agar lebih menarik misalnya dengan melakukan pengemasan, tingkat kebersihan, grading, dan packing.

\section{DAFTAR PUSTAKA}

Engel JF, Blackwell RD, dan Miniard PW. 1995. Consumer Behavior 8 th Ed. Forth Worth, Texas: The Dryden Press.

Gibson R. 2003. Dietary assessment. Di dalam: Mann J, Truswell AS, editor. Essentials of Human Nutrition. Ed ke-2. New York (US): Oxford University Press. Hlm 449-466.

Harper LJ, Deaton BJ, Driskel JA. 2009. Pangan, Gizi, dan Pertanian. Suhardjo, penerjemah. Jakarta (ID): UI Press. Terjemahan dari: Food, nutrition, and Agriculture.

Kotler P, Armstrong G. 2008. PrinsipPrinsip Pemasaran. Jilid ke-1. Ed ke-12. Sabran B, penerjemah. Jakarta (ID): Erlangga.

Mowen JC dan Minor M. 1999. Consumer Behavior. $5^{\text {th }}$ Ed. New Jersey: Prentice Hall.
Nurasrina I. 2010. Analisis hubungan pesan hemat listrik dengan kesadaran dan perilaku hemat listrik pada rumah tangga di Kota Bogor [skripsi]. Bogor (ID): Fakultas Ekologi Manusia Institut Pertanian Bogor.

Peter JP, Olson DW. 1996. Consumer Behavior and Marketing Strategy. Ed ke-4. Chicago (US): Irwin Inc.

Rogers EM. 2003. Diffusion of Innovations. $5^{\text {th }}$ ed. New York (US): Free Press.

Schiffman LG dan Kanuk LL. 2000. Consumer Behavior. $7^{\text {th }}$ Ed. New Jersey: Prentice Hall

Slamet. 1993. Analisis Kuantitatif untuk Data Sosial. Solo (ID): Dabara Pulisher.

Sumarwan U. 2004. Perilaku Konsumen: Teori dan Penerapannya dalam Pemasaran. Bogor: Penerbit Ghalia Indonesia.

Syifa ZA. 2010. Pengaruh nasionalisme konsumen terhadap niat beli dan perilaku pembelian buah-buahan [skripsi]. Bogor (ID): Fakultas Ekologi Manusia Institut Pertanian Bogor

*Siti Rochaeni (siti.rochaeni@yahoo.com)adalah

Dosen di Fakultas Sains dan Teknologi

UIN Syarif Hidayatullah Jakarta 
